\title{
UTILIZAÇÃO DE TERMOGRAFIA PASSIVA NAS INSPEÇÕES VISUAIS - ESTUDO DE CASO CONCHA ACÚSTICA DO EXÉRCITO DE BRASÍLIA
}

\author{
SOUZA, LAYANE SILVA \\ Profissão: Engenheira Civil \\ Instituição: Centro Universitário do DF (UDF) \\ Estado; País: Distrito Federal; Brasil \\ e-mail: layane.scalixto@gmail.com
}

\author{
LIMA, HENRIQUE JORGE NERY DE \\ Profissão: Engenheiro Civil \\ Instituição: Centro Universitário do DF (UDF) \\ Estado; País: Distrito Federal; Brasil \\ e-mail: hjnery@gmail.com
}

\section{RESUMO}

A inspeção visual em edificações, pontes e viadutos é um recurso importante na avaliação da segurança no qual a termografia vem se descatando por ser um ensaio não destrutivo. Visando incentivar essa técnica este trabalho tem como objetivo empregar o estudo termográfico passivo como ferramenta auxiliar no cadastro de manifestações patológicas na Concha Acústica do Exército em Brasília, procurando captar diferenças térmicas causadas principalmente por fissuras, umidade e descolamentos. Através da vistoria foram encontrados diversos problemas no sistema de impermeabilização da laje inferior como lixiviação no concreto, eflorescência, revestimento cerâmico e colapso de estrutura de vedação. A inspeção visual com o auxilio de termografia registrou a extensão dos problemas encontrados sendo possível comprovar que não basta realizar manutenções periódicas, as mesmas precisam ser coordenadas por um profissional habilitado através de um plano de manutenção que irá orientar quais sistemas devem ser verificados em um tempo definido.

Palavras-chave: termografia, inspeção, manutenção.

\section{ABSTRACT}

Visual inspection in buildings, bridges and viaducts is an important resource in the superficial safety evaluation, where thermography as a non-destructive test has been unraveling. In order to encourage the technique, the objective of this work is to use the passive thermographic as an auxiliary tool in the registration of pathological manifestations in the Concha Acústica do Exército de Brasília, seeking to capture thermal differences mainly caused by cracks, humidity and detachments. Through the inspection several problems were found in the lower waterproofing system such as efflorescence and leaching, loose ceramic floor and collapse of the structure. The visual inspection with thermography registered the extension of the problems, being possible to prove that it is not enough just to perform periodic maintenance, it is needed to be coordinated by a professional through a maintenance plan that will guide which systems should be checked within a defined time.

Keywords: thermography, inspection, maintenance.

\section{INTRODUÇÃO}

A termografia é uma técnica de inspeção não-destrutiva e não-invasiva que tem como base a detecção da radiação infravermelha emitida naturalmente pelos corpos com intensidade proporcional à sua temperatura.. (O.T.Takeda \& W. Mazer 2018, apud Bauer, 2013). De acordo com Bauer, E. et al (2014) a termografia como técnica de inspeção em edificações possui diversas vantagens pois é uma técnica não destrutiva, pode ser feita a partir de distâncias significativas, avalia as temperaturas em tempo real e seu processo de aquisição de dados é rápido. Os principais itens que variam e podem causar avaliações equivocadas nas imagens geradas por câmeras infravermelhas são emissividade, reflexo e distância. Em sua tese de doutorado, Pavon, E.(2017) destaca a importância de manter as capturas de imagens com ângulos de até $45^{\circ}$ e distância de $10 \mathrm{~m}$ justificando que a partir deste ponto o termograma possui variações indesejadas na leitura obtida. As orientações da tese citada foram mantidas para a captação dos termogramas e ao detectar uma irregularidade o operador da câmera se deslocou e modificou as perspectivas para procurar garantir uma imagem que retratasse em sua totalidade a realidade do elemento observado. 
O objetivo deste relatório é utilizar o estudo termográfico como ferramenta auxiliar no cadastro de manifestações patológicas e outras anomalias na Concha Acústica do Exército, chamando a atenção para a importância da manutenção de edificações e obras de arte especiais, principalmente a manutenção guiada por uma inspeção predial periódica. $\mathrm{O}$ resultado esperado é a captação das diferenças térmicas causadas principalmente por fissuras, umidade e descolamentos. Este estudo não substitui outros tipos de ensaios e testes mais invasivos, seu intuito é auxiliar na orientação de inspeções de possíveis não conformidades na qual a captação de áreas com variação de temperatura servirá como apoio das avaliações complementares. Para a captação dos termogramas foi utilizada a câmera infravermelha TiS60 da Fluke.

\section{METODOLOGIA}

A visita técnica foi realizada no dia 25 de maio de 2019, sendo a mesma acompanhada por dois militares do Exército Brasileiro para garantir a segurança do local em análise. Para a realização deste trabalho todos os procedimentos foram divididos nas etapas ilustradas na Figura 1:

\begin{tabular}{|c|c|}
\hline \multicolumn{2}{|c|}{ Vistoria subsolo } \\
\hline Acesso & Banheiros \\
\hline \multicolumn{2}{|c|}{ Vistoria da estrutura de concreto armado de cobertura } \\
\hline Laje superior da concha acústica & Pontos de apoio \\
\hline \multicolumn{2}{|c|}{ Vistoria da parte inferior da edificação } \\
\hline Piso & Escadas de acesso \\
\hline \multicolumn{2}{|c|}{ Conclusões } \\
\hline Organizações dos dados levantados & Avaliação dos resultados \\
\hline
\end{tabular}

Figura 1: Processos realizados na vistoria

A edificação escolhida para cadastrar as manifestações patológicas foi a Concha Acústica do Exército, localizada no Setor Militar Urbano de Brasília, entre a Praça dos Cristais e o Teatro Pedro Calmon. De acordo com informações do próprio local sua inauguração foi em 1973. O projeto, de autoria do Oscar Niemeyer, é composto por uma concha acústica de concreto armado que aumenta a amplitude sonora do ambiente, além de um pilar de sustentação no meio da estrutura (Figura 2). Na frente existe um obelisco queremete à espada de Luís Alves de Lima e Silva, sendo uma homenagem ao Duque de Caxias, patrono do exército Brasileiro. A construção está localizada em uma área plana com pouca vegetação e grande incidência de ventos. A coleta de dados foi realizada por volta de meio dia, onde as condições climáticas eram estáveis, sem presença de chuva ou nuvens.

Primeiramente foram observadas as instalações de apoio localizadas no subsolo. Não foi dado acesso livre aos ambientes, sendo possível vistoriar somente os banheiros do local. Logo no acesso ao subsolo foi possível observar manifestações patológicas nas contenções da laje de cobertura (Figura 3A) e paredes de contenção da escada (Figura 3B).

O problema observado na Figura 3A pode ter sido causado pela combinação de duas não-conformidades: falha no sistema de vedação da janela e falta de pingadeira no local. Essa combinação ocasiona lixiviação das partículas e é possível notar que em alguns casos o revestimento de argamassa e pintura estão soltos, indicando a presença de umidade. 


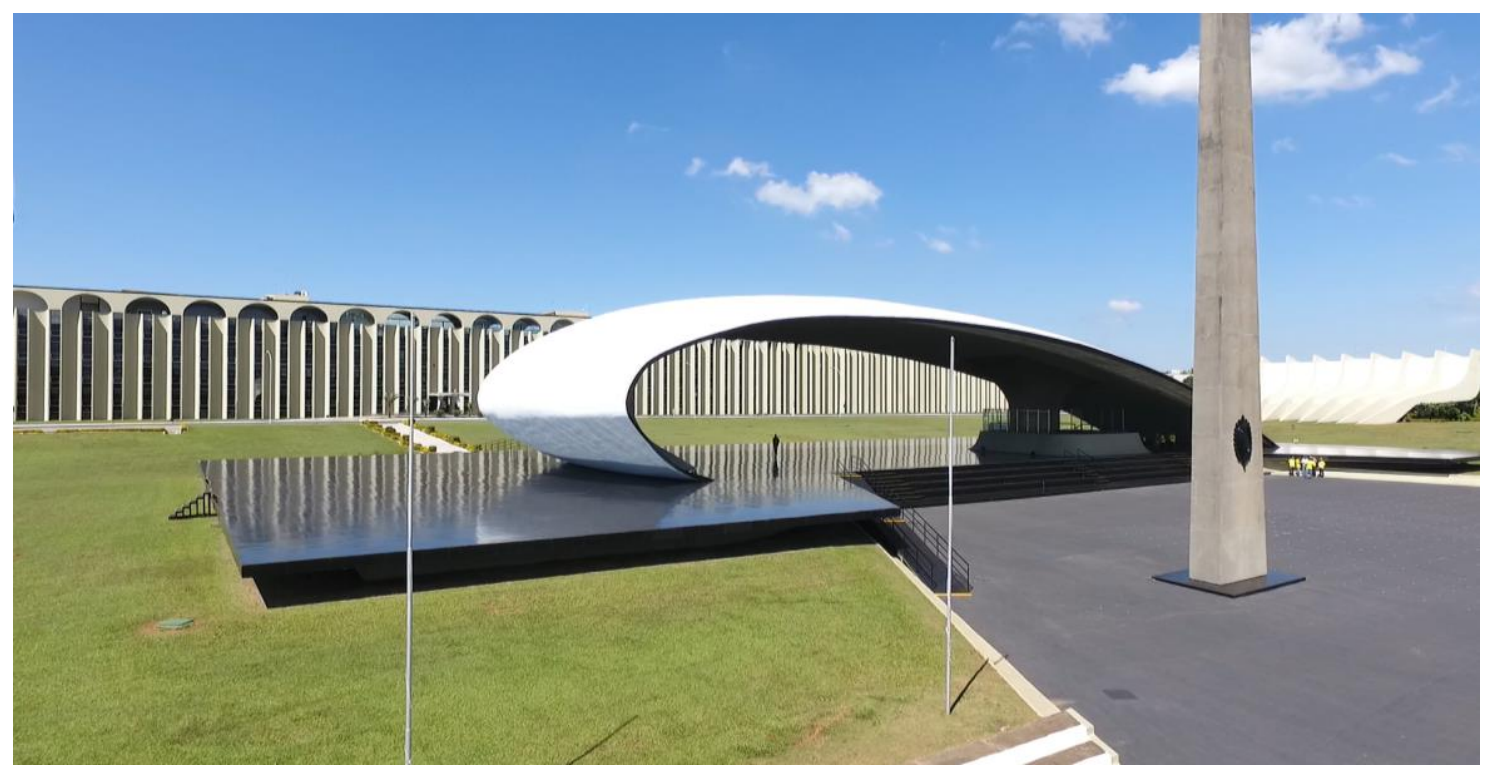

Figura 2 - Concha Acústica Militar

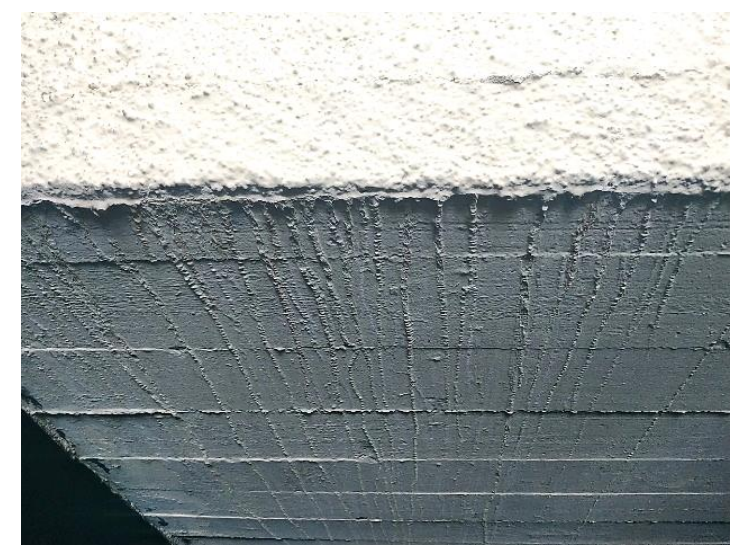

(A) Laje superior (acesso ao subsolo)

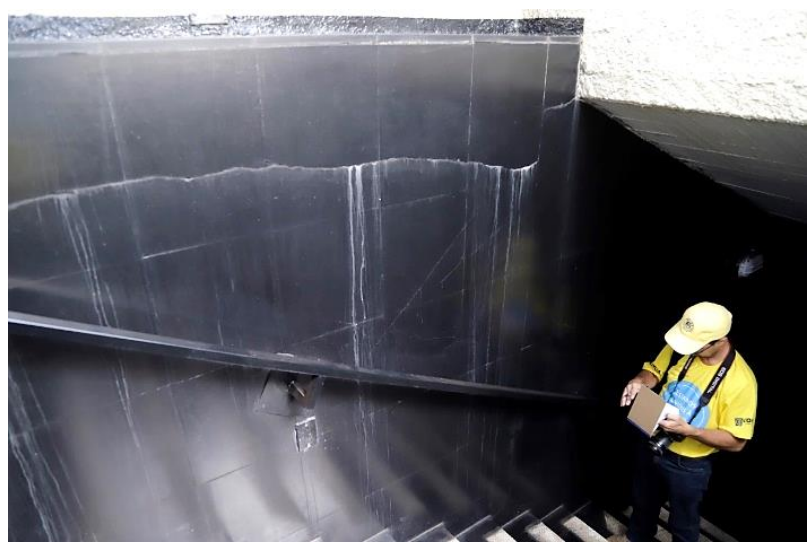

(B) Fissura na contenção com lixiviação

Figura 3: Manifestações patológicas no acesso do subsolo

Na parede de contenção da escada de acesso foram encontrados em ambos os lados fissuras com o processo de lixiviação, como pode ser visto na Figura 3. Não foi possível confirmar o tipo de contenção existente, mas considerando um sistema de vigas e blocos de concreto (ou cerâmicos) pode-se julgar como um dos motivos para tal manifestação a movimentação da parede de contenção devido à maior rigidez da parte superior através da presença de uma viga de travamento, tendo assim uma deformação não significativa. Para o estudo da origem da manifestação patológica é necessário utilizar métodos mais invasivos removendo o revestimento cerâmico e entendendo melhor o comportamento da estrutura em análise, porém não é essa a proposta do trabalho.

Adentrando nos banheiros no qual foram liberados para acesso pode-se encontrar infiltrações na laje de cobertura como observado na na Figura 4. A câmera térmica foi utilizada para confirmar se a indicação de infiltração existente era oriunda de um problema atual ou antigo, onde a mesma dtectou a variação de temperatura de $1,5^{\circ} \mathrm{C}$ devido a umidade no local.Tais infiltrações são causadas pela falha do sistema de impermeabilização externo, não sendo possível determinar na ocasião se esta era oriunda de falhas endógenas, exógenas ou funcionais. 


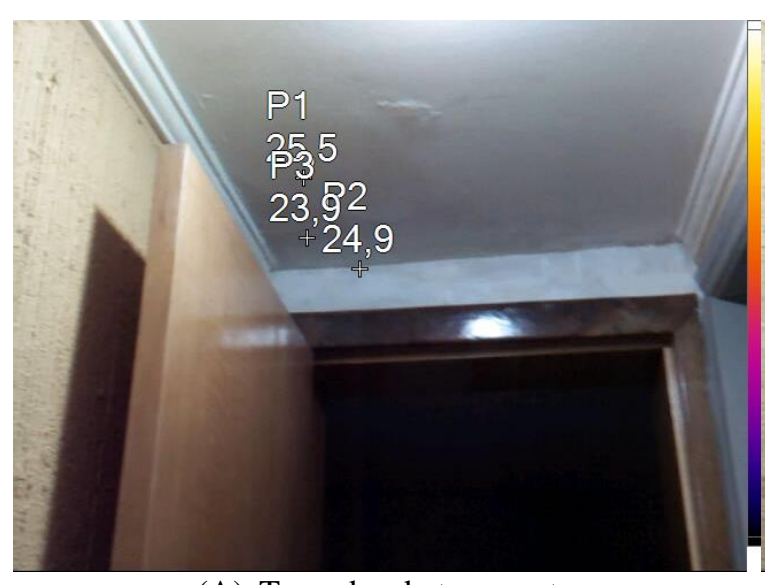

(A) Tomadas de temperatura

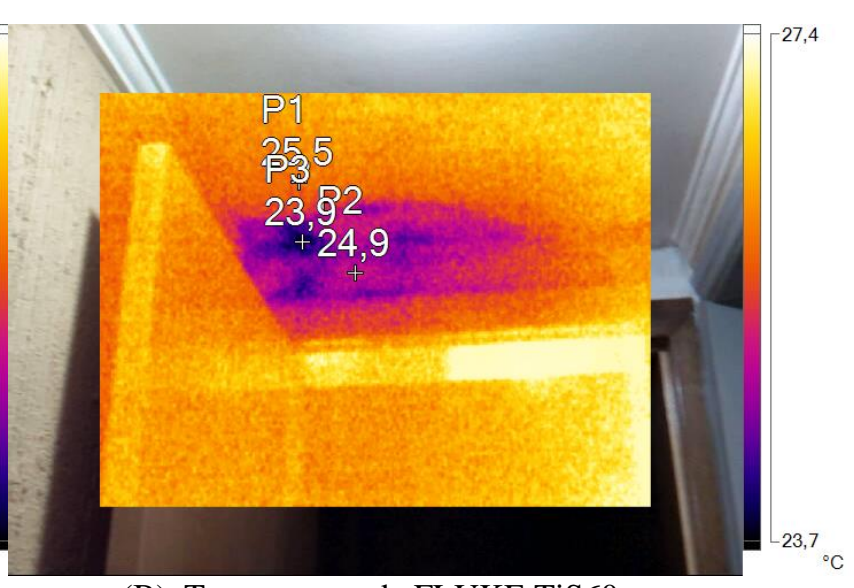

(B) Termograma da FLUKE TiS60

Figura 4: Detecção do ponto de infiltração com câmera térmica

A segunda etapa da vistoria foi realizada no térreo focando na laje superior e seus apoios. À primeira vista a edificação em estudo aparentava estar em perfeito estado de conservação possuindo manutenções recentes (pintura do ambiente, limpeza e organização), porém foram observados problemas de concepção e/ou execução. Os defeitos encontrados foram a falta de cobrimento, deixando a armadura exposta em vários pontos, e nichos de concretagem (Figura 5). As anomalias citadas deixam a estrutura suscetível à manifestações patológicas, entretanto não foram notados pontos de corrosão ou carbonatação na laje de cobertura devido às manutenções periódicas na pintura e impermeabilização.

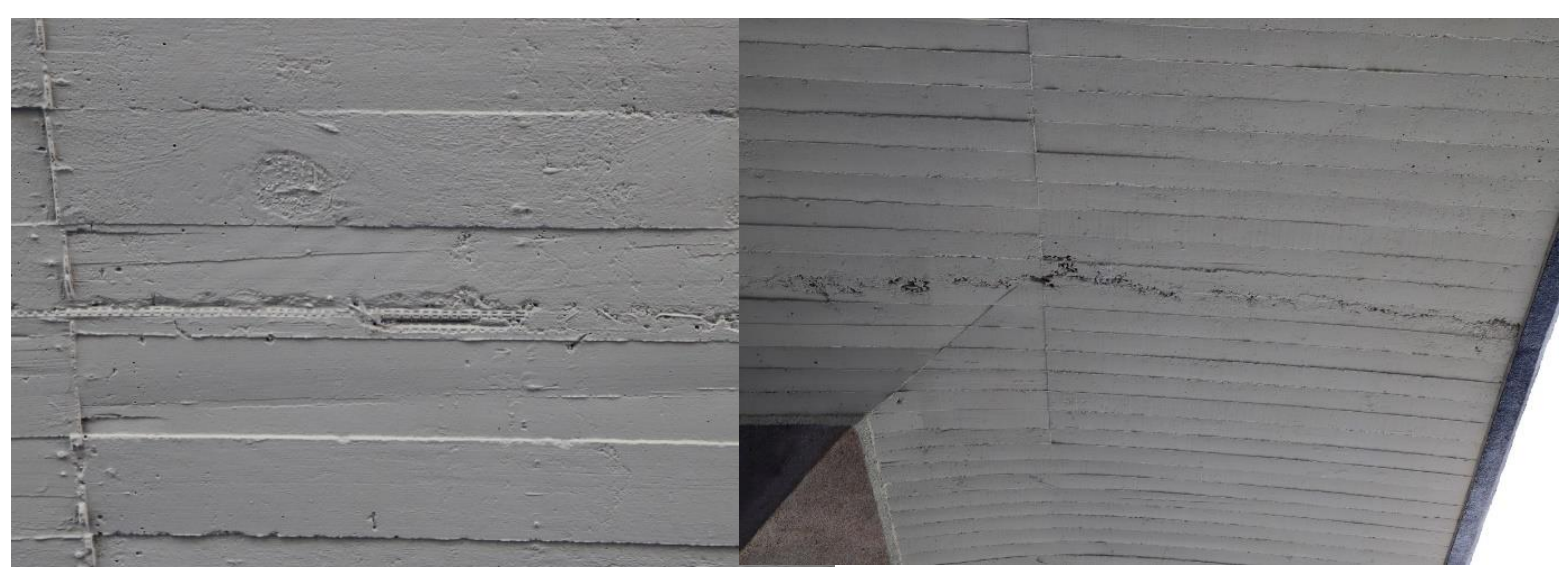

(A) Armaduras expostas

(B) Nichos de concretagem

Figura 5: Falhas de execução na Concha de Concreto Armado

A câmera térmica foi utilizada em toda a extensão da laje de cobertura, sendo captadas apenas imagens de reflexão com exceção da Figura 6, onde foi captado uma região com possível presença deumidade na base de apoio sul da concha acústica. Para confirmação de que a variação se trata de umidade e não apenas uma reflexão seria necessário utilizar uma ferramenta de medição de teor de umidade no local, não sendo a proposta deste trabalho.

Não foram encontradas muitas variações térmicas na avaliação da laje de cobertura, mas deve-se destacar que é indicado realizar a avalição em períodos diferentes do dia, levando em consideração a condição do fluxo de calor positivo e negativo na superfície analisada. No caso deste estudo a avaliação foi realizada ao meio dia por ter sido o horário liberado pelo exército, no qual o objeto em análise estava submetido à um grande aquecimento devido à alta incidência solar e por um grande intervalo de tempo, no qual a tendência é que o delta-T (variação de temperatura) entre os materiais esteja equilibrado. 


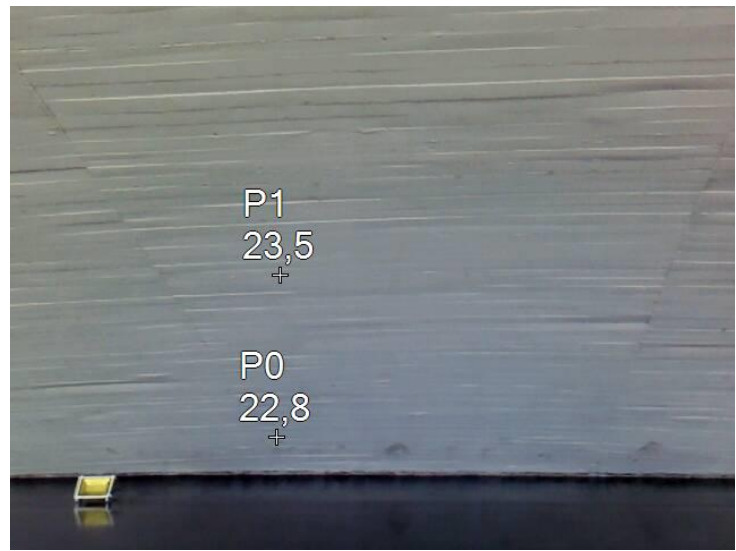

(A) Tomadas de temperatura

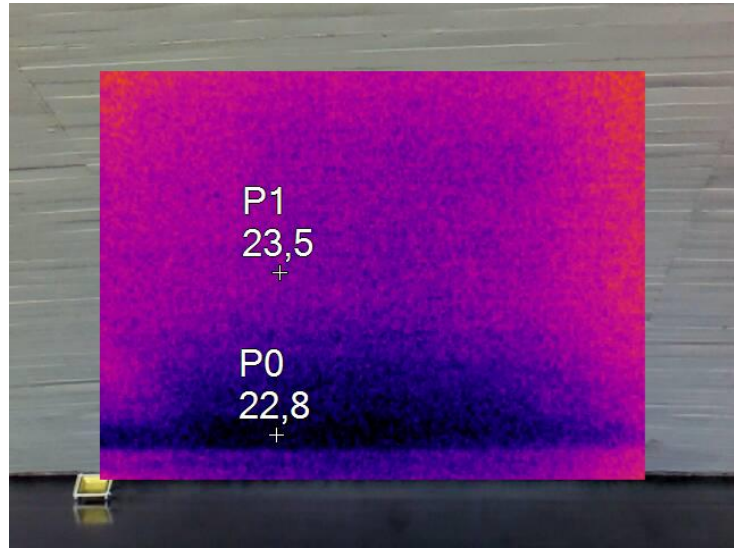

(B) Termograma da FLUKE TiS60

Figura 6: Ponto de umidade no apoio sul

Após finalizar toda a inspeção da concha (laje de cobertura) foi avaliado o revestimento cerâmico preto em toda a edificação, sendo divido em revestimento externo e interno. Durante a avaliação térmica foram constatados vários pontos com variação de temperatura (Figura 7) indicando que as placas de revestimento cerâmico em vários locais estariam soltas, o que foi confirmado através do teste de percussão com som cavo nos pontos de maior temperatura. $\mathrm{O}$ teste foi realizado em vários locais, sendo tanto nos pontos de menor temperatura quanto os de maior temperatura, onde um dos vistoriadores realizou a verificação em áreas delimitadas pelo operador da câmera térmica. Segundo a literatura de base (O.T.Takeda \& W.Mazer 2018; Bauer, E. et al 2014) na construção civil uma variação de temperatura de $1^{\circ} \mathrm{C}$ a $2^{\circ} \mathrm{C}$ geralmente é indicativo da existência de problemas e quando essa variação chega a $4^{\circ} \mathrm{C}$ ou mais, pode-se afirmar a existência de uma não-conformidade no objeto em estudo.

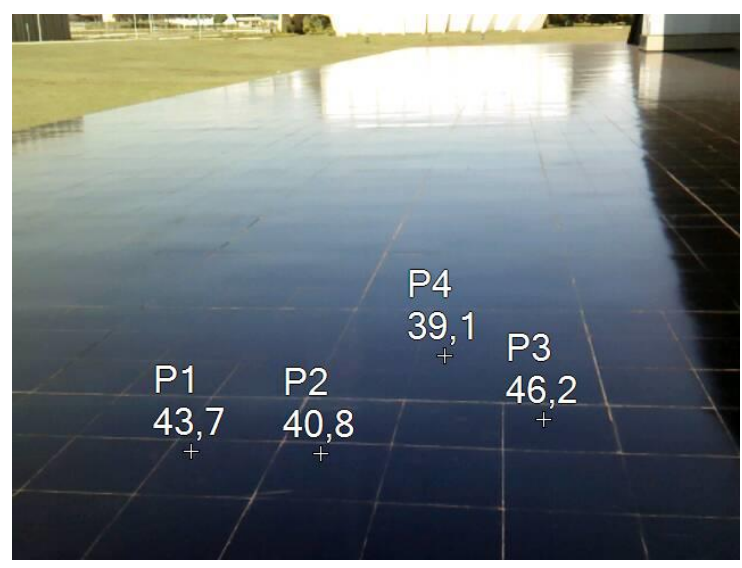

(A) Piso visão normal

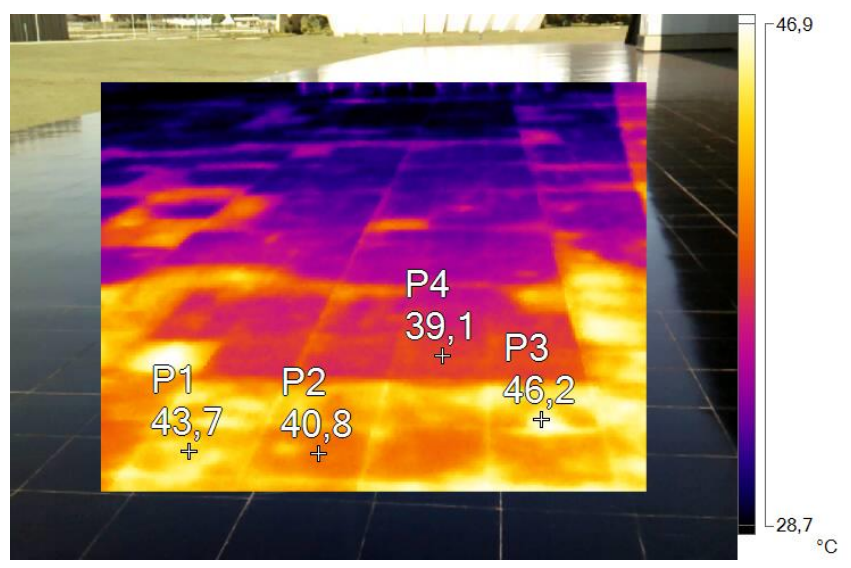

(B) Termograma da FLUKE TiS60

Figura 7: Revestimento externo solto

O revestimento cerâmico solto foi representado no termograma pela área mais quente devido ao fluxo de calor positivo, caso a superfície estivesse com fluxo de calor negativo, ou seja, perdendo calor, o revestimento descolado seria indicado como a área mais fria, porque a diferença de temperatura é dada devido ao ar contido entre a placa cerâmica e o revestimento argamassado (contrapiso). As manifestações patológicas citadas podem ser justificadas através do tipo de revestimento cerâmico escolhido e sua instalação devido ao fato de que o material de cor escura absorve uma quantidade maior de radiação solar, aumentando a sua temperatura e dilatação. Este fenômeno combinado à incidência solar constante e junta de assentamento inadequada (Figura 8A), geram tensões que ocasionam o descolamento de seu substrato. Além deste fato, foi observado que os locais onde há a junta de dilatação/movimentação do revestimento cerâmico encontram-se sem o preenchimento adequado (Figura 8B). 


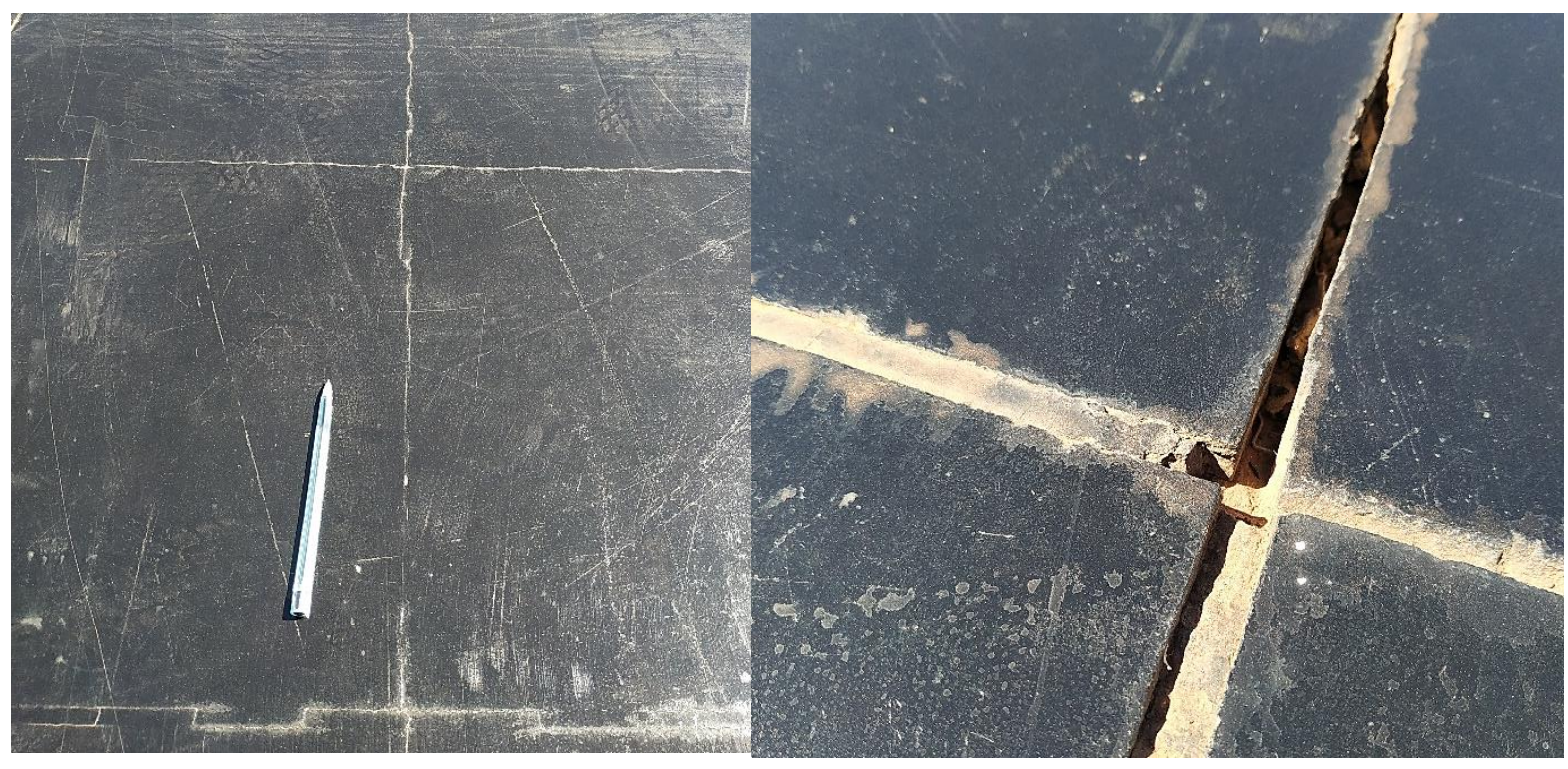

(A) Revestimento sem juntas espaçadas

(B) Juntas danificadas

Figura 8: Detalhe no revestimento externo

Após a constatação dos revestimentos soltos na área externa (sendo este padrão não encontrado na parte interna), a quarta etapa da inspeção foi verificar a laje de piso inferior porque a Concha Acústica tem sua construção suspensa e parte encontra-se em balanço. Iniciou-se a vistoria examinando o acesso posterior ao gramado no qual encontra-se uma escada de concreto armado e rampa adaptada para a acessibilidade em estrutura metálica. Na escada de acesso foram observadas diversas manifestações patológicas no lance, patamar e pilar de apoio (Figura 9).

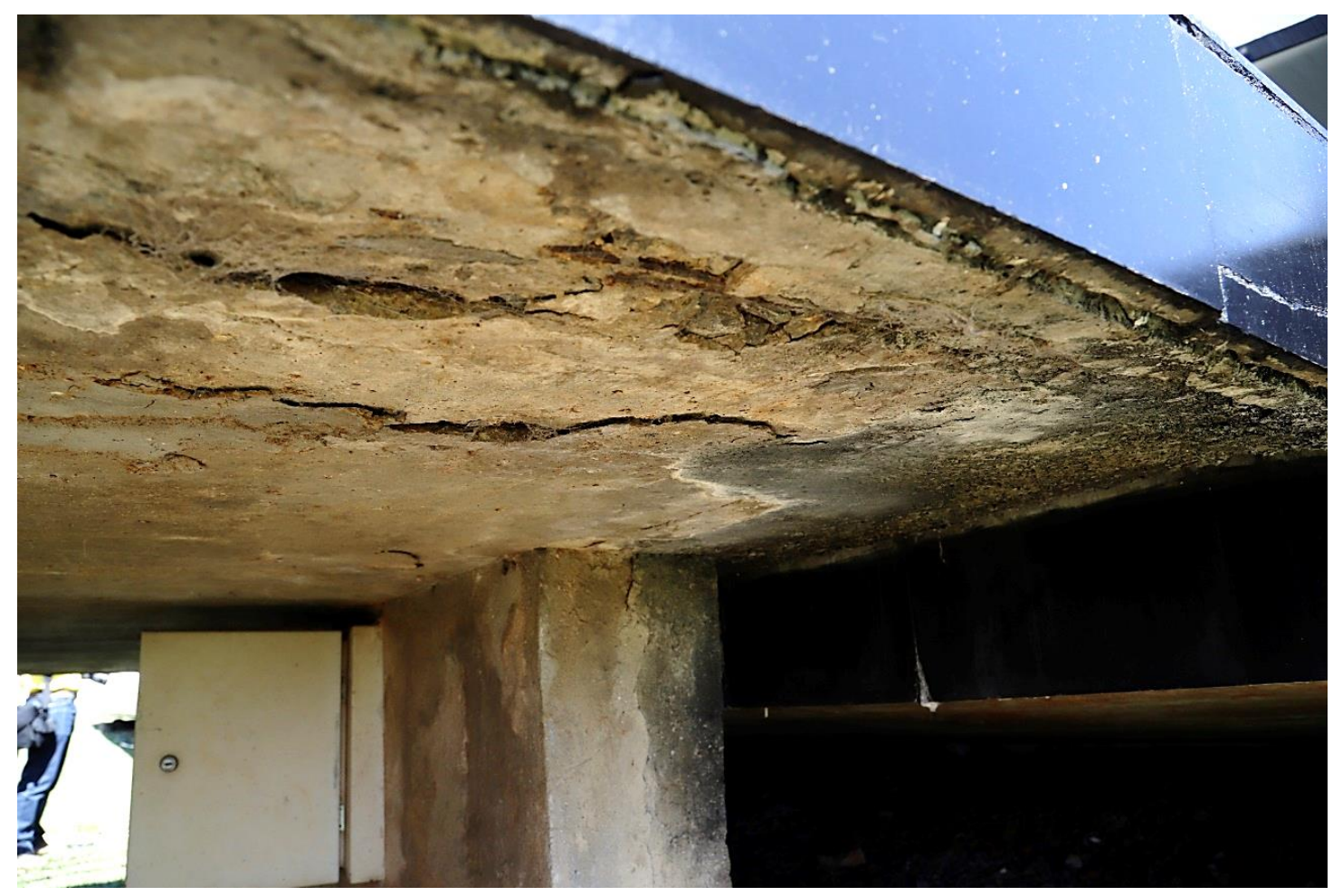

Figura 9: Laje com desplacamento de concreto e armadura exposta

Na Figura 9 é possível verificar que a laje do patamar está com armadura exposta, em processo de corrosão, com desplacamento do concreto e vários indícios de infiltração. Os problemas citados podem ser oriundos pela falha de 
impermeabilização e a falta de uma pingadeira eficiente na borda de sua estrutura. O pilar de apoio da escada também possui indicação de armadura com processo de corrosão (Figura 10A), sendo visualizadas regiões onde a mesma encontra-se exposta (Figura 10B). Pode-se notar também a quantidade de zonas indicativas de infiltração com presença de microrganismos tanto na laje quanto no pilar em questão. Foram tomadas imagens térmicas dos locais conforme a Figura 11 sendo constatado certa variação de temperatura no qual o local acima da estrutura encontrava-se seco, sem água de limpeza ou pluvial.

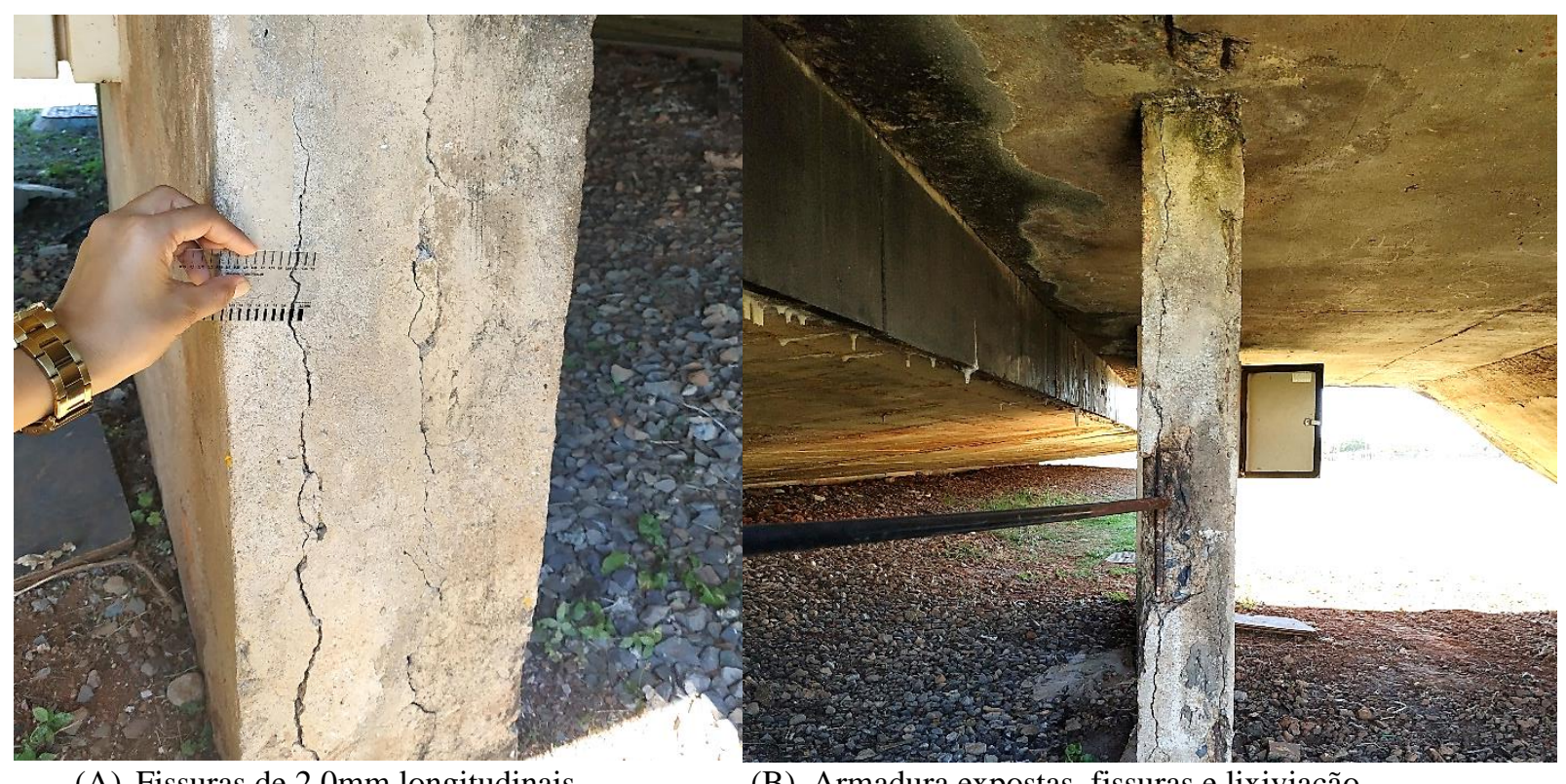

(A) Fissuras de 2,0mm longitudinais

(B) Armadura expostas, fissuras e lixiviação

Figura 10: Manifestações patológicas no pilar de apoio

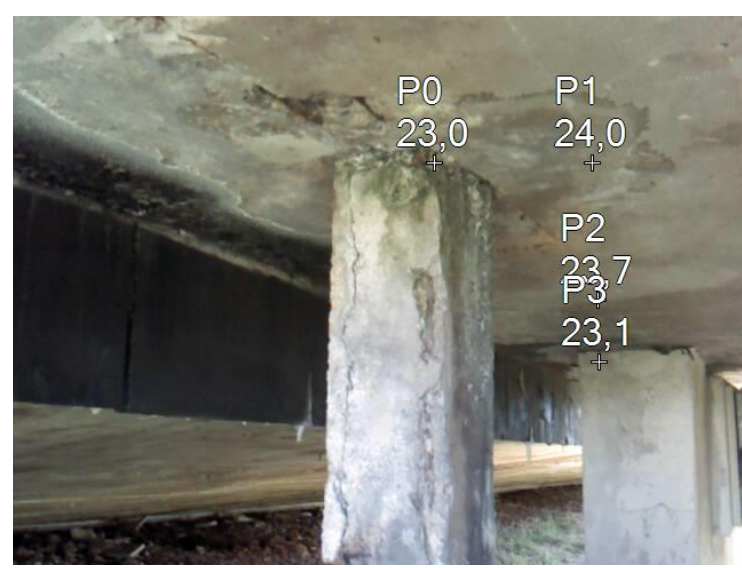

(A) Tomada de temperatura

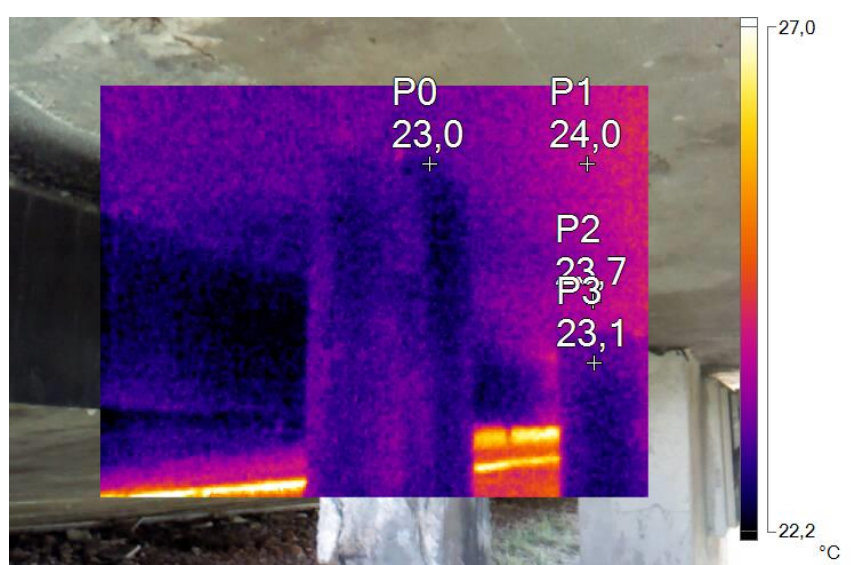

(B) Termograma da FLUKE TiS60

Figura 11: Avaliação térmica do pilar de apoio da escada

Seguindo a avaliação da escada foram encontrados pontos de eflorescência no apoio do lance conforme a Figura 12 , podendo ser visto no termograma pontos com concentração de umidade evidenciados como os pontos mais frios devido ao fluxo de calor positivo do ambiente. 


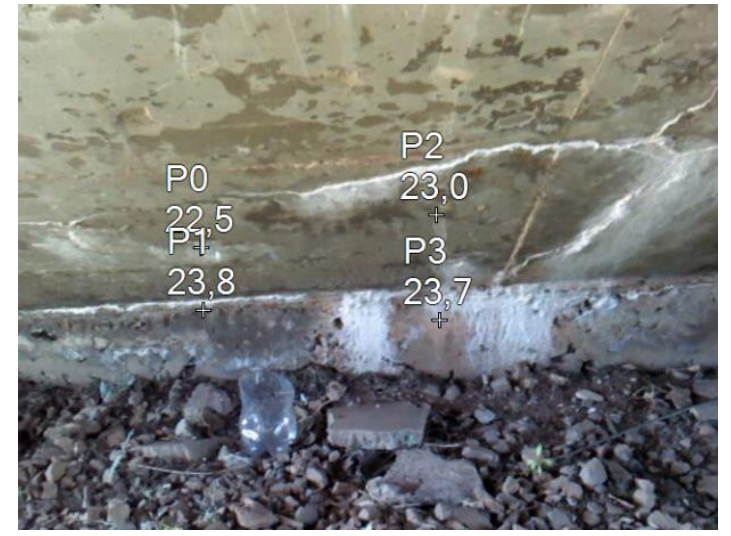

(A) Tomada de temperatura

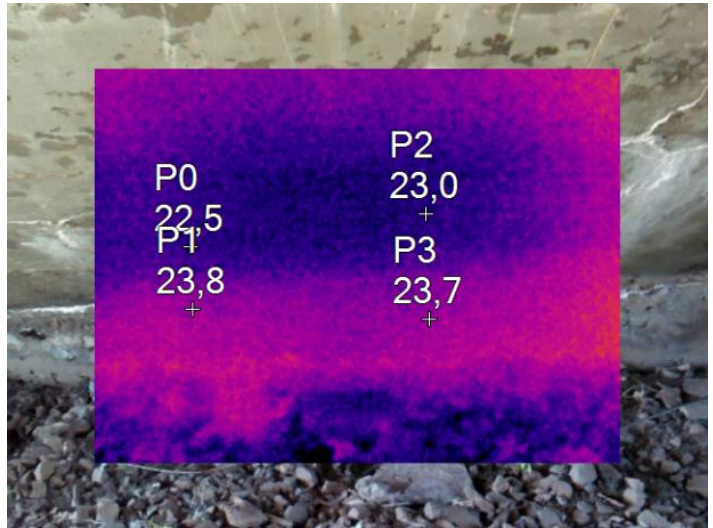

(B) Termograma da FLUKE TiS60

Figura 12: Eflorescência no apoio do lance da escada

Por fim, foi registrado outra área de infiltração de grande incidência na transição entre a laje do patamar da escada e a laje de piso com a presença de microrganismos, depósitos de hidróxido de cálcio e magnésio causados pela a lixiviação do concreto. Nestes locais foram encontradas poucas variações térmicas, podendo indicar que a recorrência é maior em períodos de chuva e momentos de limpeza do local.

Dando continuidade ao reconhecimento das lajes inferiores que formam o balanço da estrutura encontrou-se vários pontos com estalactites formadas devido à lixiviação do concreto (Figura 13) no qual a presença da água infiltrada pela estrutura gerou saturação do solo. As formações de estalactites devem-se à dissolução do hidróxido de cálcio existente no concreto carregado junto ao fluxo da água.

A presença de pontos com lixiviação indica uma possível falha no sistema de impermeabilização em toda a continuidade da estrutura, podendo também ser associada aos problemas encontrados no revestimento cerâmico externo, onde seu destacamento pode ter sido fator adicional na diminuição da vida útil de impermeabilização. Não foi informado a periodicidade de manutenção da edificação ou se o sistema foi refeito desde sua construção de forma a garantir a estanqueidade da estrutura, por isto para tratar tais não-conformidades faz-se necessário um estudo das condições da laje inferior com remoção de pontos estratégicos do revestimento cerâmico para examinar melhor as camadas existentes.

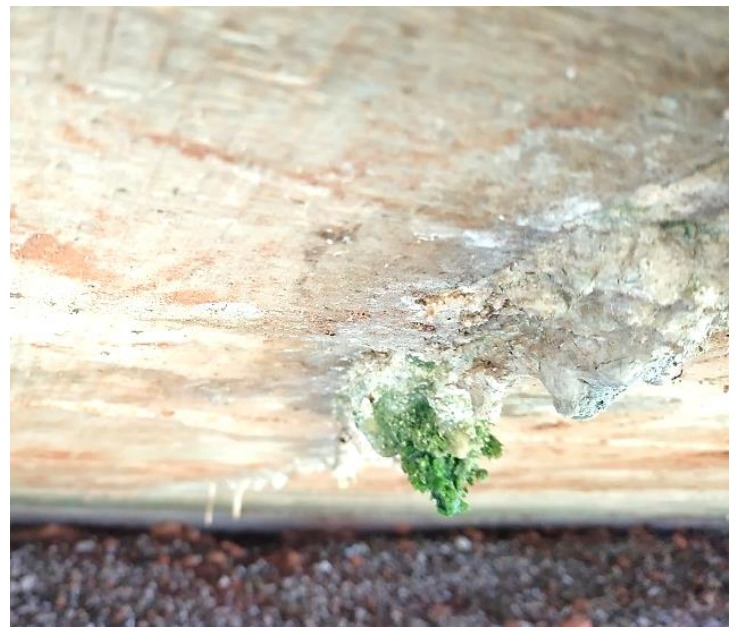

(A) Estalactites com microrganismos

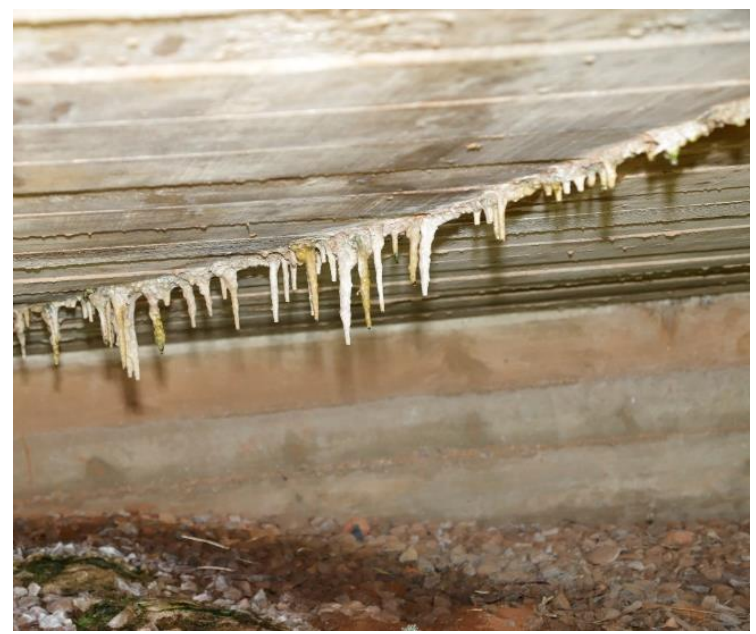

(B) Estalactites devido a lixiviação

Figura 13: Estalactities na laje inferior

Como forma de validação dos pontos aqui relatados foi capturada uma imagem térmica do ponto de lixiviação (Figura 14), onde foi possível verificar a diferença de $6,5^{\circ} \mathrm{C}$ entre o ponto seco da estrutura e o ponto com eflorescência. 


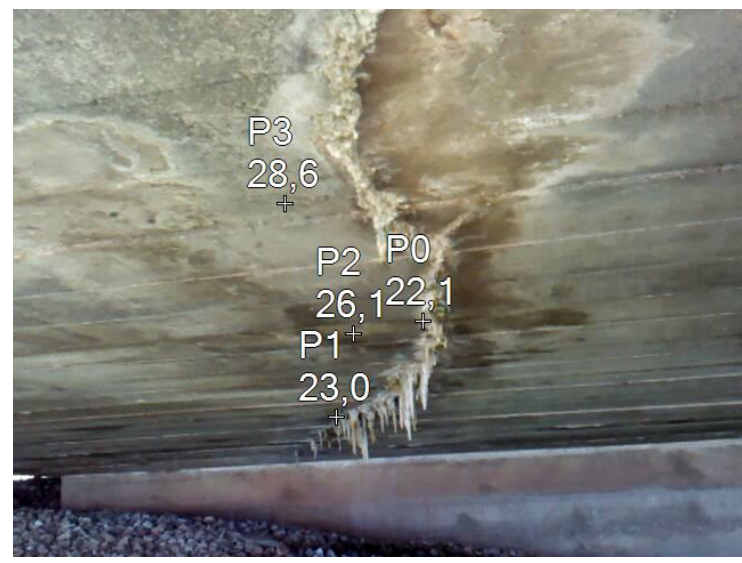

(A) Tomadas de temperatura

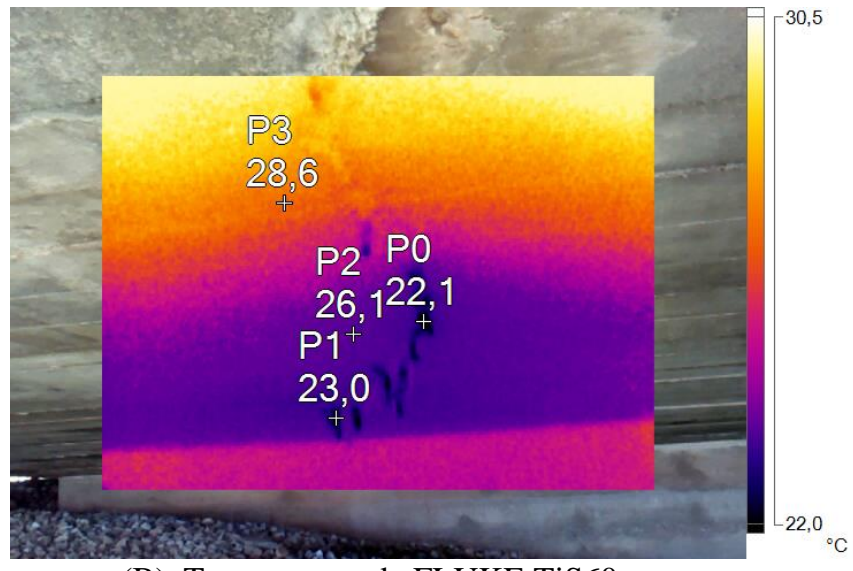

(B) Termograma da FLUKE TiS60

Figura 14: Avaliação realizada com câmera térmica

Outros problemas oriundos da presença de umidade foram encontrados ao longo da estrutura de contenção. Como pode ser visualizado na Figura 15A, a contenção está com presença de eflorescência. Esse problema surgiu devido a falta de pingadeira na estrutura (Figura 15B), no qual a água da superfície escorre em todo o seu comprimento e se deposita na estrutura, dissolvendo os sais do concreto e aflorando, em sua maioria, o hidróxido de cálcio.

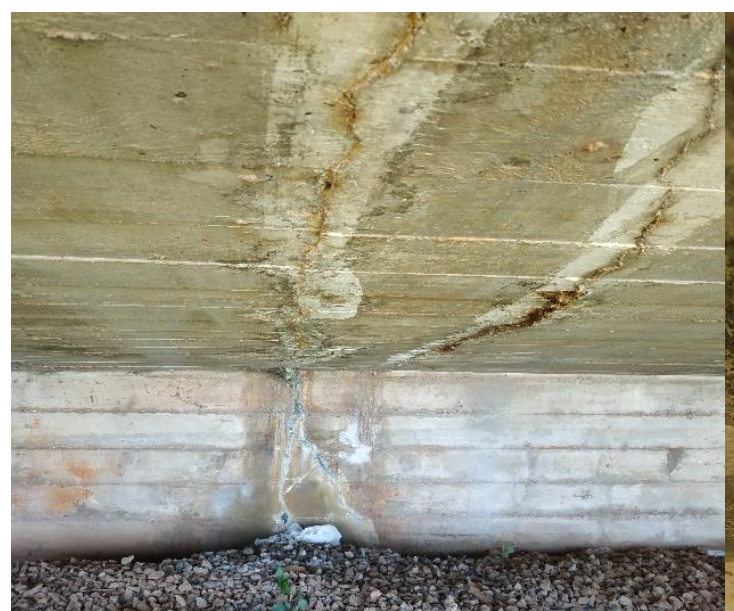

(A) Eflorescência na contenção

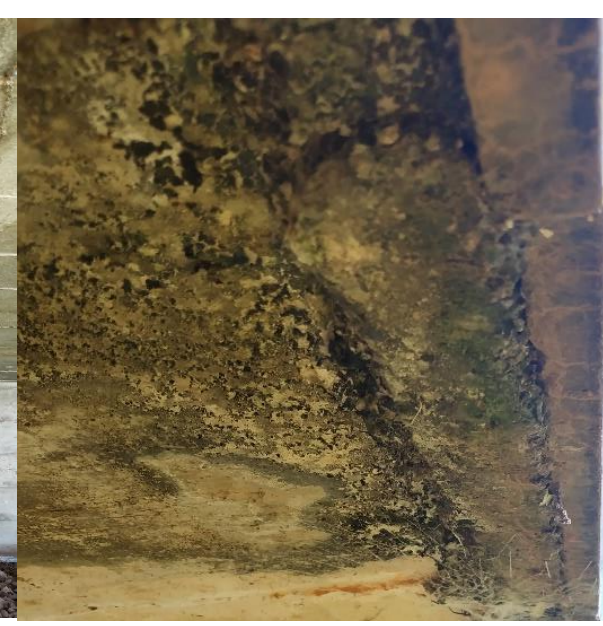

(B) Extremidade da laje inferior

Figura 15: Eflorescência na contenção

Próximo à finalização da quarta etapa foi encontrado um problema grave no lado sul da concha acústica, sendo observado um local onde houve colapso parcial da laje inferior da estrutura de vedação (Figura 16). Não foi determinado o motivo do colapso da estrutura porém seu interior foi vistoriado e foram encontrados pontos com falhas de execução, umidade e fissuras. Através da observação da Figura 16 é possível entender melhor a forma que foi projetada a laje em balanço, com vigas trapezoidais e laje inferior de acabamento.

Com a câmera termográfica foram tomadas temperaturas e capturados termogramas para entender as diferenças encontradas, obtendo-se uma variação de até $2,1^{\circ} \mathrm{C}$ de acordo com a Figura 17, sendo o ponto mais frio indicativo de presença de umidade devido ao fluxo de calor positivo. 


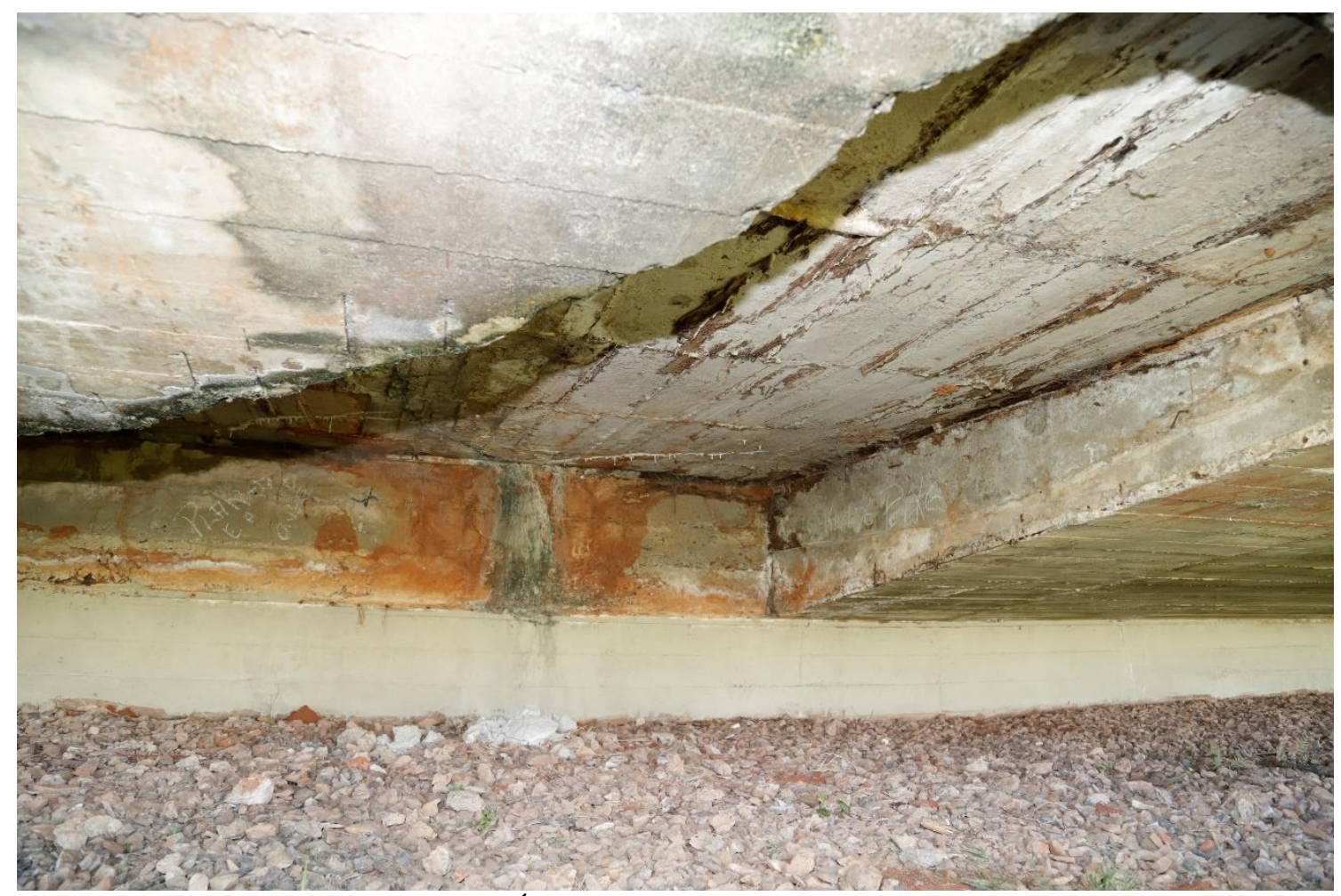

Figura 16: Área onde houve colapso da estrutura

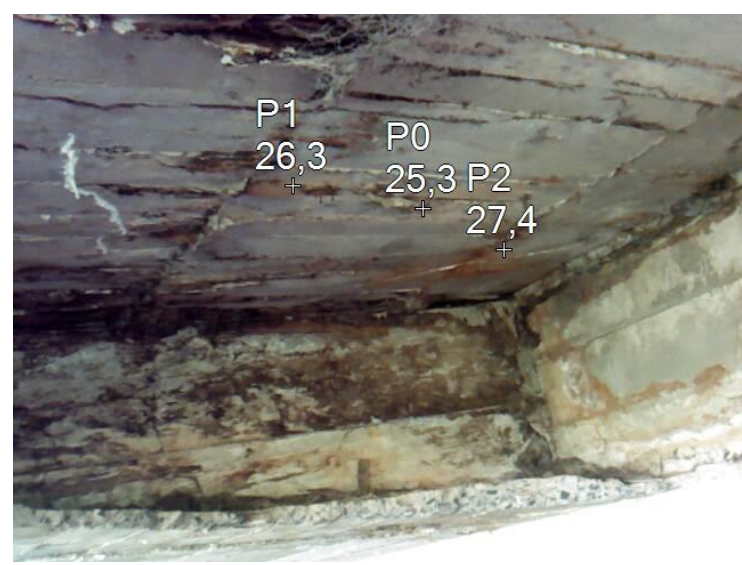

(A) Tomada de temperatura

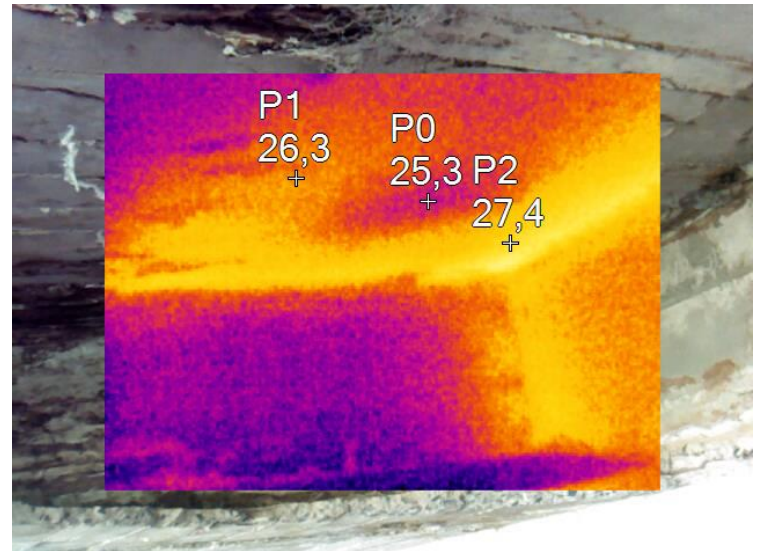

(B) Termograma FLUKE TiS60

Figura 17: Imagens térmicas no local do colapso

Ao verificar a viga de apoio pode-se encontrar nichos de concretagem e armaduras expostas, as quais são provenientes de falhas de execução e/ou concepção, podendo diminuir a resistência do elemento nos pontos indicados. Ao verificar lajes e parede de contenção foram encontradas fissuras preocupantes que se interligam e podem ser visualizadas nas Figura 18 e Figura 19. A Fissura na parede de contenção é vertical (Figura 18) e perpendicular à seção transversal da estrutura, enquanto a fissura longitudinal a laje (Figura 19) é observada em quase toda a sua extensão, conectando-se com a fissura vertical da parede de contenção. Ressalta-se que tais manifestações patológicas precisam ser avaliadas com urgência, junto com as causas do colapso da estrutura inferior. 


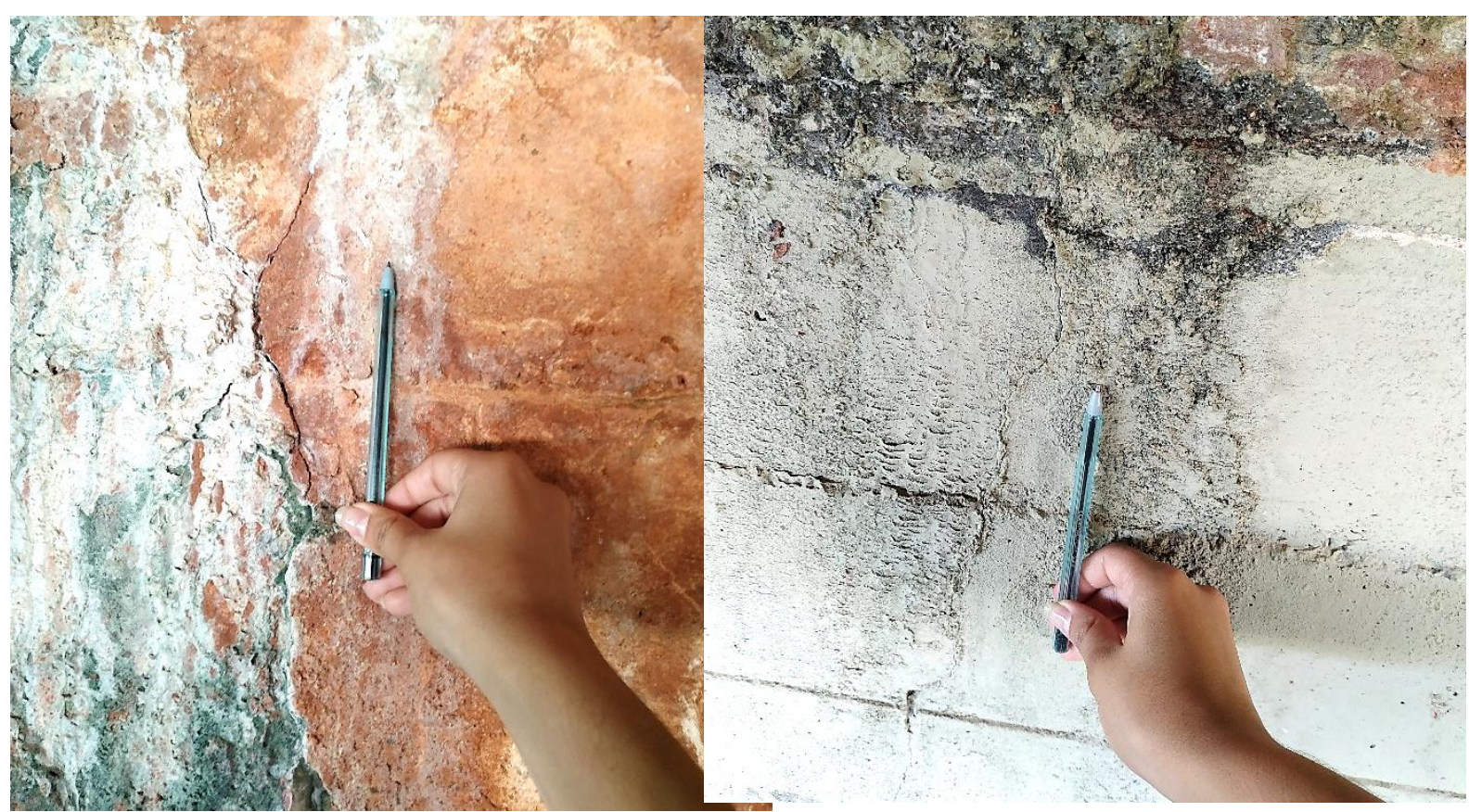

(A) Parede de contenção da estrutura

(B) Continuação da fissura na parede

Figura 18: Fissura vertical na estrutura de contenção

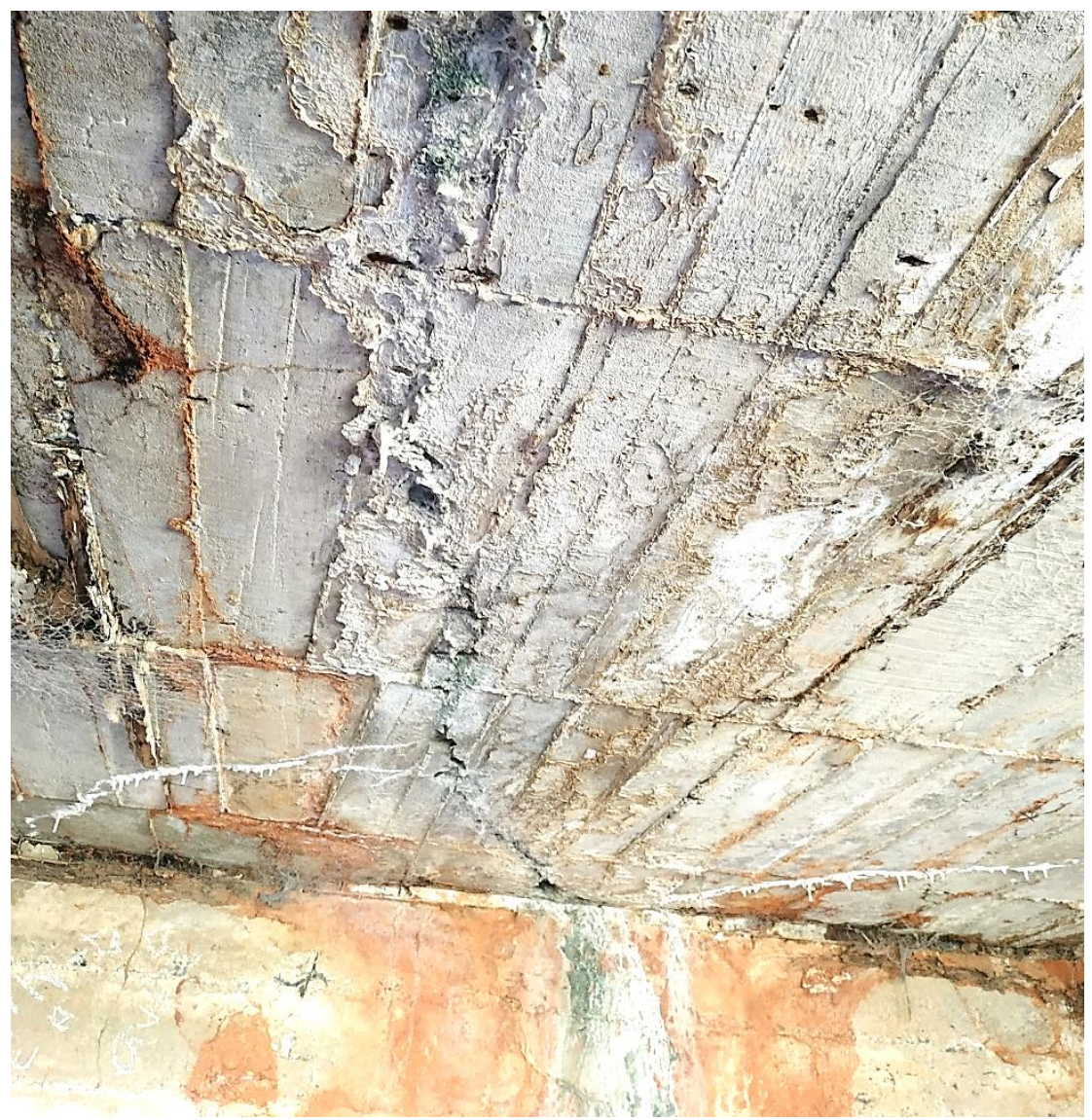

Figura 19: Fissura transversal na laje superior e da parede de contenção 


\section{CONCLUSÕES}

Apesar da estrutura de concreto armado da Concha Acústica do Exército possuir manutenções recentes, a mesma encontra-se em estado de atenção. Faz-se necessário uma orientação técnica através de uma inspeção detalhada das verificações e manutenções das estruturas inferiores porque foram encontrados elementos estruturais com corrosão de armaduras, desplacamento de concreto, locais com pontos de infiltração, lixiviação, eflorescência e até mesmo estalactites, formadas devido a dissolução dos sais da estrutura. Ressalta-se a necessidade imediata de uma perícia detalhada avaliando a região onde houve colapso parcial da estrutura e a presença de fissuras na parte remanscente. Recomenda-se também que esta avaliação seja estendida para outros pontos da edificação, atuando de forma preventiva impedindo que o mesmo possa ocorrer em outros locais.

Não foi possível, com este estudo, determinar se a falha no sistema de revestimento cerâmico foi de concepção e execução ou apenas em uma das etapas. Desta forma orienta-se uma investigação mais profunda de todos os revestimentos soltos e possível substituição do piso, onde deve ser realizado novamente o sistema de impermeabilização da estrutura verificando também se não há manifestações patológicas como fissuras, trincas, carbonatação e outros que possam prejudicar a vida útil da estrutura. Além disso, ressalta-se a necessidade da execução de elementos de "pingadeira" onde a água deverá ser retida antes de passar para a estrutura.

Os resultados encontrados com a avaliação térmica foram considerados satisfatórios em razão de que através destes foi possível verificar a extensão do revestimento solto e confirmar que manifestações patológicas como lixiviação e eflorecência eram oriundas de problemas recentes devido aos termogramas com temperatura inferior indicando a presença de umidade nos pontos inpecionados. Cabe ressaltar que os termogramas capturados não isentam outros tipos de testes como por exemplo ensaio de percussão, carbonatação e outros, mas podem direcionar locais mais específicos para realizar os ensaios complementares.

Em decorrência dos dados aqui levantados pode-se concluir que é imprecindível realizar uma inspeção visual para a orientação das manutenções das edificações, pois apesar de ser possível identificar a preocupação com a manutenção da construção, esta foi voltada apenas para a pintura e impermeabilização da estrutura superior da edificação sem observar que na estrutura inferior da edificação surgiram manifestações patológicas que não foram corrigidas como: corrosão das armaduras, falta de impermeabilização, fissuras na estrutura e até mesmo colapso de uma laje de vedação. A utilização do termograma auxiliou no diagnóstico preliminar dos problemas encontrados e através das imagens captadas é possível orientar possíveis perícias em relação às não-conformidades apontadas neste estudo de caso.

\section{REFERÊNCIAS}

ABENDI. “Associação Brasileira de Ensaios Não destrutivos,.” Técnicas e Ferramentas para Ensaios Não Destrutivos. São Paulo, Novembro de 2017.

ASSOCIAÇÃO BRASILEIRA DE NORMAS TÉCNICAS. NBR 10520: Informação e documentação - Citações em documentos - Apresentação. Rio de Janeiro, 2002.

ASSOCIAÇÃO BRASILEIRA DE NORMAS TÉCNICAS. NBR 6023: Informação e documentação - Referências Elaboração. Rio de Janeiro, 2018.

BAUER, E.; CASTRO, E.K.; OLIVEIRA FILHO, A.H.; PAVÓN, E.A. (2014). Critérios para aplicação da termografia de infravermelho passiva como técnica auxiliar ao diagnóstico de patologias em fachadas de edifícios. $1^{\circ}$ Encontro Luso-Brasileiro de Degradação em Estruturas de Concreto Armado. Salvador, BA. 10p.

BAUER, L.A.F. Materiais de Construção. (2008). Rio de Janeiro, RJ: LTC - Litros Técnicos e Científicos Editora S.A, $5^{\text {a }}$ Ed Revisada. Volume 1, 471 páginas.

TAKEDA, O.T.; MAZER, W. (2018). Potencial da análise termográfica para avaliar manifestações patológicas em sistemas de revestimentos de fachadas. Revista ALCONPAT Internacional, Volume 8, Número 01. 12p.

PAVON, E. (2017). Critérios e padrões de comportamento para avaliação de descolamentos cerâmicos com termografia de infravermelho. Tese de Doutorado, Publicação E.TD-6A/17, Departamento de Engenharia Civil e Ambiental, Universidade de Brasília, Brasília- DF, 250p. 